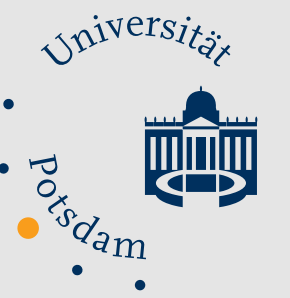

Humanwissenschaftliche Fakultät

Annett Hüttges | Doris Fay

\title{
The Gender-Differential Impact of Work Values on Prospects in Research Careers
}

Suggested citation referring to the original publication:

Journal of Career Development 42(6) (2015)

DOI https://doi.org/10.1177/0894845315582246

ISSN (print) 0894-8453

ISSN (online) 1556-0856

Postprint archived at the Institutional Repository of the Potsdam University in:

Postprints der Universität Potsdam

Humanwissenschaftliche Reihe ; 402

ISSN 1866-8364

http://nbn-resolving.de/urn:nbn:de:kobv:517-opus4-404849 



\title{
The Gender-Differential Impact of Work Values on Prospects in Research Careers
}

\author{
Annett Hüttges' and Doris Fay ${ }^{2}$
}

\begin{abstract}
Women are strongly underrepresented at top positions in research, with some research suggesting the postdoctoral career stage is a critical stage for female researchers. Drawing on role congruity theory and social cognitive career theory, we tested the gender-differential impact of work values (extrinsic rewards-oriented work values and work-life balance values) on subjective career success and supports from supervisors (leader-member exchange) and team members. We conducted an online survey with male and female postdoctoral scientists $(N=258)$. As hypothesized, the positive relationship between extrinsic rewards-oriented work values and subjective career success and supports was stronger for male researchers than for female researchers. Results on work-life balance values were less conclusive. These findings support the idea that gendered appraisal processes may affect career-relevant outcomes.
\end{abstract}

\section{Keywords}

gender, work values, career success, supervisor support, team support, gender differences, role congruity theory, social cognitive career theory

Despite their increasing level of education and training, as well as their considerable participation in employment in the research sector, women are still dramatically underrepresented at upper levels of academic and research institutions. Scientific advice is strongly needed for dealing with future societal challenges. Therefore, it is crucial to understand barriers of female career development in research and academic contexts in order to leverage the full potential of a society's human capital.

The underrepresentation of women is a ubiquitous phenomenon. In 2008, less than a quarter of the highest level of professorships in Germany were held by women. In nonuniversity research institutions, the percentage was even lower, with only $14 \%$ of women holding chairs (cf. Figure 3

\footnotetext{
' Helmholtz-Centre Potsdam, GFZ German Research Centre for Geosciences, Potsdam, Germany

${ }^{2}$ Department of Psychology, Work and Organizational Psychology, University of Potsdam, Potsdam, Germany

Corresponding Author:

Annett Hüttges, Helmholtz-Centre Potsdam, GFZ German Research Centre for Geosciences, Human Resources Development, Telegrafenberg, 14473 Potsdam, Germany.

Email: huettges@gfz-potsdam.de
} 
in Graf, Dautzenberg, Büttner, \& Schmid, 2011, p. 24). There is also a marked gap in the level of assistant professors, where $26 \%$ of these positions were held by women at universities and only $15.5 \%$ at nonuniversity research institutions (cf. Figure 1 in Graf et al., 2011, p. 22).

In contrast to the popular view that it is a matter of time for highly qualified women to progress through a career "pipeline" in order to assume leadership positions, German panel data covering more than 20 years suggest that time will not solve the problem. Female underrepresentation cannot be attributed to too few women entering or completing higher education or obtaining a doctoral degree. The share of female full professors in 2003-2005 reached only $20 \%$, which was substantially lower than the female share of university graduates in the 1990s (almost 40\%), and it was also lower than the female share of total doctoral degrees awarded (less than 30\%; cf. Lind \& Löther, 2007). Thus, it is not a matter of time for highly qualified women to ascend the career ladder. Instead, academic and research careers suffer from a "leaky pipeline," in Germany as well as elsewhere (Buckley, Sanders, Shih, Kallar, \& Hampton, 2000; Burrelli, 2008). However, in Germany, the underrepresentation of women in upper positions is particularly striking compared to a large part of the European Union. This applies to the private as well as the public sector (European Commission, 2013; Holst \& Schimeta, 2011).

The lack of women in top positions has been studied in various disciplines, some focusing more on structural barriers (i.e., lack of childcare) that purportedly prevent women from investing sufficient time and energy necessary for career progress, whereas others focus on more subtle psychological processes (i.e., appraisal processes). From the perspective of role congruity theory, how work behaviors and work results are perceived, interpreted, and evaluated is biased by gender (Eagly \& Karau, 2002). Because of the descriptive as well as prescriptive component of gender roles, behaviors that are critical for career advancement tend to be devalued or even penalized if exhibited by women.

The present article draws on role congruity theory and social cognitive career theory (SCCT) to explore the role of work-related values for research careers. An abundance of research rooted in role congruity theory has shown that work behaviors (e.g., Heilman \& Chen, 2005) and work outcomes (Heilman \& Haynes, 2005) have gender-differential effects. We go beyond the study of behaviors and outcomes by studying values. Work values, job attribute preferences, and the associated career goals are all related to career progress and success (Abele \& Spurk, 2009b; Frieze, Olson, Murrell, \& Selvan, 2006; Konrad, Yang, Goldberg, \& Sullivan, 2005). Role congruity theory suggests that there may be an impact of gender on the relationship between values on the one hand and outcomes on the other. Thus, based on role congruity theory, we test for a gender-contingent impact of work values on outcomes that are relevant for career prospects in research. According to SCCT (Lent, Brown, \& Hackett, 1994), values operate as "preferences for particular work conditions" (Lent, Brown, \& Hackett, 2002, p. 267) and interact with social contextual factors (i.e., supervisors, team members) that affect self-regulatory processes, the so-called adaptive career behaviors, and career attainments (Lent \& Brown, 2013). Overall, our research objectives are twofold. We examine the role of two types of work values for career success indicators that are relevant for further career prospects, and second, we seek to test whether the value-career success relationship would differ between men and women.

\section{Success in Research Careers}

In order to obtain a better understanding of the processes underlying the female underrepresentation in top positions in research, it is useful to focus on a career stage that is critical for further ascendance to top positions and thus most informative to unravel gender-differential paths. In research careers, this stage appears to be the postdoctoral phase. Based on a longitudinal study conducted in the United States and in Canada, the authors concluded that gender starts to matter 
most after PhD graduation: “... we were able to observe an initial pattern of non-discrimination for newly minted $\mathrm{PhD}$ graduates that shifts to a pattern of differential results ..." (Miller, Glick, \& Cardinal, 2005, p. 511). Furthermore, research on the "leaky pipeline" indicates that the loss of women in research careers is particularly high in the postdoctoral career stage (European Commission, 2013).

Focusing on a confined career stage has implications for the conceptualization of career success. The most frequently used measures of career success in terms of level of position or pay (Heslin, 2005) cannot be applied because there is little variance in these career attainments at this specific career stage. ${ }^{1}$ We conceptualize career success as comprising two components: first, the subjective assessment of career success, and second, the level of supports attracted that are relevant for further career attainments. They are relevant because of their impact on further career prospects.

Early career success is a useful construct because it predicts later career success (Dreher \& Bretz, 1991). Regarding subjective career success, Heslin (2005) distinguishes between a selfreferent assessment and an other-referent success evaluation. Here, we follow the latter conceptualization of success: the other-referent career success evaluation refers to the assessment of one's own career relative to the attainments and expectations of significant others (Heslin, 2005). It captures the individual's assessment of how well he or she is doing compared to what others have achieved (e.g., peers) and compared to expectations of relevant others (e.g., supervisors). It relies on social comparison and is based on the signals and feedback received by others. A subjective other-referent success measure is appropriate for the context of the present study because individuals rely heavily on comparisons with others when objective indicators are missing (e.g., such as differences in pay or job level; cf. Heslin, 2005). Furthermore, other-referent measures are useful because they are related to objective measures (Abele \& Spurk, 2009a). They are meaningful in an ongoing career. In the context of career development in research, early career success predicts later career success (Hadani, Coombes, Das, \& Jalajas, 2012; Judge, Kammeyer-Mueller, \& Bretz, 2004).

We conceptualize the level of supports from the environment as a second indicator of success. Upward career mobility, from the perspective of "sponsored mobility," is the consequence of the amount of special attention and support from established elites in the occupational field (Turner, 1960). The sponsored-mobility approach highlights the significance of support from various stakeholders in the organization. In particular, the supervisor plays an important role through providing access to networks, resources, or opportunities and thus predicts career success ( $\mathrm{Ng}$, Eby, Sorensen, $\&$ Feldman, 2005). This finding also applies to the context of research (Jungbauer-Gans \& Gross, 2013).

Furthermore, the level of support provided by the team is relevant. In research, a large amount of work is conducted in teams (Ludlow \& Kent, 2011). A supportive team makes available a wide breadth of knowledge, skills, and abilities to team members. This resource is conducive to individual learning (De Dreu, 2007) and supports the development of domain-specific expertise and human capital. Human capital, in turn, is related to career success ( $\mathrm{Ng}$ et al., 2005). Thus, we conceptualize the perception of support from the supervisor and from the team as further indicators of success at the postdoctoral career stage.

\section{Work Values and Careers}

Work values (Beutell \& Brenner, 1986), also called job attribute preferences (Konrad, Ritchie, Lieb, \& Corrigall, 2000), are defined as job characteristics and work outcomes people desire and feel motivated to attain. Work values are increasingly studied in the context of career achievements (Abele \& Spurk, 2009b; Frieze et al., 2006; Konrad et al., 2005). In comparison to the typically 
studied antecedents of career success and career-relevant outcomes (e.g., human capital, mentoring, cf. $\mathrm{Ng}$ et al., 2005), values are more distal but nevertheless relevant predictors of career achievements (Abele \& Spurk, 2009b; Frieze et al., 2006). According to SCCT (Lent \& Brown, 2013; Lent et al., 1994), work values and preferences influence adaptive career behaviors such as selfregulatory processes that interact with social-contextual factors to initiate several achievement behaviors. Thus, they are predictors of individual motivation, behaviors, and decisions (Bardi \& Schwartz, 2003), and in turn, work values, job attribute preferences, and associated career goals are related to career progress and success (Abele \& Spurk, 2009b; Lyness \& Judiesch, 2008). SCCT has also been successfully applied to the examination of gender differences in interest development, choice making, performance, persistence, and turnover in different vocational contexts, among others of science, technology, engineering, and mathematics (STEM) careers (Lent \& Brown, 2013; Singh et al., 2013).

Values affect career success to the extent that they enhance the types of behaviors and attitudes that are encouraged, rewarded, and appreciated in the context under study. Given the purpose of the present research, we focus on extrinsic rewards-oriented work values and work-life balance values. We define extrinsic rewards-oriented work values as the motivation and desire to achieve an esteemed and influential position in the work domain, whereas we define work-life balance values as the desire to attain working conditions that permit the balancing of work with other domains of life. Both types of work values are of relevance for career success because they have implications for allocation of individual resources and behaviors and the impact that both have on the environment. More importantly, extrinsic rewards-oriented and work-life balance values are gendered (Konrad, Ritchie, et al., 2000; Warr, 2008) and thus likely to have gender differential impacts. In most Western industrialized societies, men are expected to act in an agentic way, while women are expected to act in a communal way (Heilman, 2001). Extrinsic rewards-oriented values and work-life balance values are differentially aligned with these roles (Konrad, Corrigall, Lieb, \& Richie, 2000), such that they should unfold gender-differential impacts (Eagly \& Karau, 2002). We discuss both in turn.

\section{Extrinsic Rewards-Oriented and Work-Life Balance Work Values}

Career success in research institutions is, to a considerable extent, based on the principles of meritocracies in which an individual's career success is contingent upon the visible contributions made to the overall goals (Judge et al., 2004). Data from human resource professionals working in the headquarters of German research organizations as well as data from senior researchers (e.g., heads of research institution, tenured professors) suggest that the contributions determining career success are time and energy consuming (Fay, Hüttges, \& Graf, 2013). Work values and preferences influence choices about time and resource allocation and about the relative investment of time and energy in work or nonwork commitments. Extrinsic rewards-oriented work values should be positively related to subjective other-referent career success. Increasing levels of extrinsic rewards-oriented work values should be associated with corresponding efforts and attitudes. Efforts and attitudes are perceived by others, such as the supervisor and colleagues. Based on those observations, they form an impression and assessment of the individual's contributions. This assessment, in turn, offers feedback to the individual, influencing the individual's subjective career success.

Work-life balance values should be negatively associated with subjective career success because work-life balance values promote a reasonable limitation of the overall level of work commitments in favor of fulfilling nonwork commitments as well. Again, efforts and attitudes associated with work-life balance values are perceived by others, and their observations will affect their responses toward the individual, which influence subjective career success assessments. 
Hypothesis 1: Extrinsic rewards-oriented work values are positively related, and work-life balance values are negatively related, to subjective career success.

Work values should also affect the level of supports given by the supervisor and the team. Following SCCT, these sources of support function as contextual supports or barriers for career attainment (Singh et al., 2013). The main objectives of supervisors and team members are to reach high research output. While a supervisor benefits from high output in terms of prestige, the team may even be affected in terms of its livelihood. The behaviors and attitudes associated with the values benefit or hinder the supervisor and the team to obtain their goals. In particular, higher levels of extrinsic rewards-oriented values should be more instrumental for achieving a high research output, while the reverse applies to higher levels of work-life balance values. From a perspective of reciprocity, the supervisor and the team offer support to the individual to the extent that the individual supports the pursuit of goals (Blau, 1964).

Hypothesis 2: Extrinsic rewards-oriented work values are positively related to career supports, whereas work-life balance values are negatively related to career supports.

\section{Gender as a Moderator of the Value-Outcome Link}

Past research has shown that the same behaviors can result in different outcomes, depending on the gender of the actor (Heilman \& Chen, 2005; Heilman \& Haynes, 2005). These findings have been explained by social role theory and role congruity theory (Eagly \& Karau, 2002). Related to the social roles of "breadwinner" and "homemaker," social role theory argues that communal and agentic attributes are the key to differential beliefs about men and woman. One implication of role congruity theory is that if individuals do not act in accordance with their social role, the incongruent gender-role behaviors will be devalued or penalized.

Extrinsic rewards-oriented work values are aligned with the expectation toward men to act in an agentic way. In contrast, for women, extrinsic rewards-oriented work values are not in congruence with their role expectations. This might lead to a devaluation of the extrinsic rewards-oriented work values for women, and the displayed values and associated efforts may be perceived and acknowledged in a far lesser way in comparison to men (Heilman \& Haynes, 2008). Information on a given actor-values, behaviors, and attitudes - are interpreted in line with expectations. Information not aligned with expectations is more likely not to be attended to, not interpreted appropriately and stored in memory (Heilman \& Haynes, 2008). We therefore expect a weaker relationship of extrinsic rewards-oriented values with subjective career success and career supports for women.

Hypothesis 3: Gender moderates the relationship between extrinsic rewards-oriented work values and subjective career success and career supports, such that the positive relationship is stronger for men than for women.

By contrast, work-life balance orientation is more aligned with the stereotypical belief of women as communal beings. If men hold higher levels of work-life balance orientations, this might not be perceived and remembered (Heilman \& Haynes, 2008). Thus, the proposed negative effect of work-life balance values on subjective career success and career supports should be milder for men than for women. By contrast, for women, work-life balance orientation is aligned with their social role and the expectations that people hold toward women.

Hypothesis 4: Gender moderates the relationship between work-life balance values and career success and career supports, such that the negative relationship is weaker for men than for women. 


\section{Method}

\section{Participants and Procedure}

We tested the hypotheses in a sample of 258 postdoctoral scientists from different nonuniversity research institutions in Germany. Data analyzed here are part of a larger study on career development in sciences. Seven hundred scientists participated in the study by responding to an online survey. For reasons given above, we focus on individuals in the postdoctoral stage.

To recruit study participants, we contacted administrative headquarters of different nonuniversity research institutions. They were informed about the project on career development in research and they were asked to support the study. After these administrative headquarters expressed the institution's general consent to participate, they received an e-mail invitation including a web link. Headquarters forwarded this e-mail either to the heads of the research institutes or directly to scientific staff. Participation in this study was voluntary, and the confidentiality of the responses was assured. Four weeks after the first mailing, we sent a follow-up mailing to our contact persons.

The postdoctoral subsample comprised 258 persons, $57.4 \%$ were women, and $42.6 \%$ were men. This study focuses on postdoctoral researchers because this stage is regarded as critical for further career development. We therefore excluded 19 postdoctoral researchers who were older than 55 years because by German law they exceeded the age limit for being appointed to professor. Seventy-nine percent of the scientists worked in the so-called mathematics, information technology, natural sciences, technology (MINT) subjects; this is a cluster of research fields equivalent to what is known in other countries, such as the United States, as STEM. In all analyses, we controlled for age, family status, parenthood, and the nature of employment contract (number of working hours according to contract; tenured) because they could act as confounding variables. For example, gender differences in work values are also a function of parenthood (Ferriman, Lubinski, \& Benbow, 2009). Furthermore, family responsibilities can impact time available for work. Thus, we assessed parenthood (55.9\% of the participants had one or more children) and marital status $(83.0 \%$ were married or in a partnership). Furthermore, we turned our attention to the employment contracts of the scientists. About one third of the sample (36.4\%) had a tenured employment contract, whereas $63.6 \%$ of the participants were temporally employed. Contracted hours per week were 36.73 on average $(S D=6.59)$. Age of the participants ranged from 24 to 55 years $(M=39.09$, $S D=6.88)$. This age range is higher than what one would typically find in other research contexts (i.e., at universities), and it includes more senior researchers. It is the result of German nonuniversity research institutions having the leeway to retain qualified researchers by offering tenure positions. Tenure positions are one strategy to keep researchers in research institutions instead of losing them to attractive posts in the industry.

\section{Measures}

All data were collected as self-reports with an online-based survey. Measures that were originally in English were either used in their academically published German translation or translated into German and checked by a bilingual psychologist.

Work values. Work values were measured with items adapted from the Work Value Survey (Warr, 2008). Participants were asked to evaluate the significance of several work values (e.g., "a responsible job") on a 5-point Likert-type scale ranging from not important at all to very important. Two types of work values were assessed: work-life balance values and extrinsic rewards-oriented work values. Work-life balance values were measured with 3 items: "good hours," "generous holidays," and "not too much pressure." Extrinsic rewards-oriented work values were assessed with 5 items: "good 
chances of promotion," "good pay," “a responsible job," “a respected job," and "autonomy with regard to research focus."

Items were factor analyzed to test for the presumed two-dimensional construct. All items showed factor loadings higher than the critical value of .40 by convention and the scree test suggested a two-factor solution from the diagram of the eigenvalues. Nevertheless, the item "good pay" from the Work Value Survey (Warr, 2008) was eliminated because of high cross loadings (i.e., loadings on both factors between .40 and .50). Cronbach's $\alpha$ for the final scales was .65 for work-life balance values and .66 for extrinsic rewards-oriented work values. As Hirschi (2010) notes, lower reliabilities of work value measures can be expected not only because of the small number of items but also because the different value items represent different aspects regarding contents or outcomes of work, which by themselves do not need to be highly related. This is aligned with the concept of causal indicator model instead of effect indicator model (Bollen \& Lennox, 1991).

Providing some evidence for construct validity, postdocs with children had a significantly higher level of work-life balance values $(M=3.21, S D=0.75)$ than postdocs without children, $M=2.98$, $S D=0.74 ; F(1,252)=5.77, p<.05$; in contrast, there was no significant difference in extrinsic rewards-oriented work values. Moreover, striving for professorship as a career goal was associated with a significantly higher level of extrinsic rewards-oriented work values, $M=4.00, S D=0.62 ; F(2,247)=$ $9.07, p<.001$, in comparison to striving for employment as a researcher at a university or nonuniversity institutions as a career goal $(M=3.71, S D=0.51)$ and other career goals (e.g., employed in a laboratory in the industry, becoming self-employed, consultant in politics, further alternatives; $M=3.59$, $S D=0.63)$. None of the effects were confounded by gender.

Subjective career success and career supports. We used 3 items to assess other-referent subjective career success (Abele \& Wiese, 2008). Subjective career success is related to objective measures of success (Abele \& Spurk, 2009b). It includes comparative judgments of one's own success, with the referent being significant others such as former fellow students (Abele \& Wiese, 2008) and team members (e.g., "Compared with those of your former fellow graduates, who are also doing research, how successful do you think you are?" "Compared with the other members of your team, how successful do you think you are?"). Additionally, participants were asked to estimate how their supervisor would perceive their career success. This 3-item measure was based on a 5-point rating scale from 1 (not successful) to 5 (highly successful). Cronbach's $\alpha$ was .77. In a large sample of professionals, otherreferent subjective career success was associated with self-set career goals and goal-pursuing behavior (e.g., career planning) (Abele \& Wiese, 2008). In a longitudinal study, other-referent career success predicted objective career success (Abele \& Spurk, 2009a).

We assessed support from the supervisor by employing a measure of leader-member exchange (LMX). LMX relates to the perceived quality of the dyadic relationship between supervisor and employee. Following Graen and Uhl-Bien (1995), LMX is based on "(1) mutual respect for the capabilities of the other, (2) the anticipation of deepening reciprocal trust with the other, and (3) the expectation that interacting obligation will grow over time as career-oriented social exchanges blossom into a partnership" (p. 237). According to this definition, we employed the LMX7 scale by Graen and Uhl-Bien (1995; German version by Schyns, 2002). Participants were asked to evaluate the quality of their individual relationship with their supervisor (e.g., "How would you characterize your working relationship with your leader?" [4 items] on a 5-point Likert-type scale). Cronbach's $\alpha$ was .89. According to meta-analytic findings, there are significant relationships between LMX and positive work outcomes such as job performance, work satisfaction, commitment, and member competence, and negative relationships with turnover intentions (Gerstner \& Day, 1997). Moreover, LMX contributed to project success in research and development teams (Elkins \& Keller, 2003). 
Team support was assessed with 3 items adapted from the Survey of Perceived Organizational Support (Eisenberger, Huntington, Hutchison, \& Sowa, 1986) for which participants used a 7-point Likert-type scale from 1 (strongly disagree) to 7 (strongly agree). Adapting the original items to the context of the team, participants were asked about their global beliefs concerning the extent to which the team "values their contributions and cares about their well-being" (Eisenberger et al., 1986, p. 501). Item wording was as follows: "The team cares about my general satisfaction at work," "The team takes pride in my accomplishments at work," and "The team would ignore any complaint from me" (recoded). Cronbach's $\alpha$ for the 3 items was .72. There is indirect empirical evidence for construct validity of our team support measure. Items are parallel with items of the team climate inventory (e.g., "feel understood and accepted by each other"; Anderson \& West, 1998) which is related to team innovativeness.

\section{Results}

The hypotheses were tested with moderated hierarchical regression analyses. Table 1 displays means, $S D$ s, internal consistency coefficients (Cronbach's $\alpha$ s), and correlations between study variables.

We examined Hypotheses 1-4 simultaneously by using hierarchical moderated regression analyses; we then plotted the results. Predictors, but not the dichotomous moderator, were standardized (cf. Aiken \& West, 1991; Dawson, 2013). Control variables (Step 1), extrinsic rewards-oriented work values, work-life balance values as well as gender (Step 2), and the interaction terms of both types of work values and gender (Step 3) were entered in subsequent steps. First, subjective career success was regressed on extrinsic rewards-oriented work values, work-life balance values, and their products with gender to test the interaction effect of work values and gender on subjective career success. In the same way, LMX and team support were regressed on this set of variables (Table 2).

In line with Hypothesis 1 , extrinsic rewards-oriented work values positively predicted subjective career success $(\beta=.31, p<.01$; Table 2$)$; partially supporting Hypothesis 2 , there was also a significant effect on team support $(\beta=.23, p<.01$; Table 2$)$. In contrast, work-life balance values were not significantly associated with any of the three outcomes variables (Hypothesis 1 and 2).

Supporting Hypothesis 3, gender moderated the relationship between extrinsic rewards-oriented work values and subjective career success $(\beta=-.82, p<.05$; Table 2$)$, LMX $(\beta=-1.14, p<.01$; Table 2$)$, and team support $(\beta=-.92, p<.05$; Table 2$)$.

Plots of the interactions show the slopes at $1 S D$ above and below the mean of extrinsic rewardsoriented work values (cf. Figures 1-3). The simple slope for the relationship between extrinsic rewards-oriented work values and subjective career success (Figure 1) was significantly positive for men $(\beta=.22, t=4.90, p<.01)$ but not for women $(\beta=.04, t=0.92, p=.36, n s)$, which supports Hypothesis 3. The simple slope for the relationship between extrinsic rewards-oriented work values and LMX (Figure 2) was nonsignificant for men $(\beta=.01, t=0.19, p=.85, n s)$ and significant in a negative direction for women $(\beta=-.30, t=-4.81, p<.01)$. Last, the simple slope for the relationship between extrinsic rewards-oriented work values and team support (Figure 3) again was significantly positive for men $(\beta=.28, t=3.38, p<.01)$ but not for women $(\beta=-.06, t=-.68$, $p=.50, n s)$. Overall, there was strong support for Hypothesis 3.

We simultaneously tested the moderating role of gender on the relationship between work-life balance values and outcomes (Hypothesis 4). Contrary to this prediction, there was no significant moderation for subjective career success and team support. There was only a significant negative interaction of gender and work-life balance work values on LMX. Similar to extrinsic rewardsoriented work values and LMX the simple slope was nonsignificant for men $(\beta=.02, t=0.32$, $p=.75, n s)$ but significant in a negative direction for women $(\beta=-.34, t=-6.24, p<.01)$. Overall, there was limited support for Hypothesis 4. 


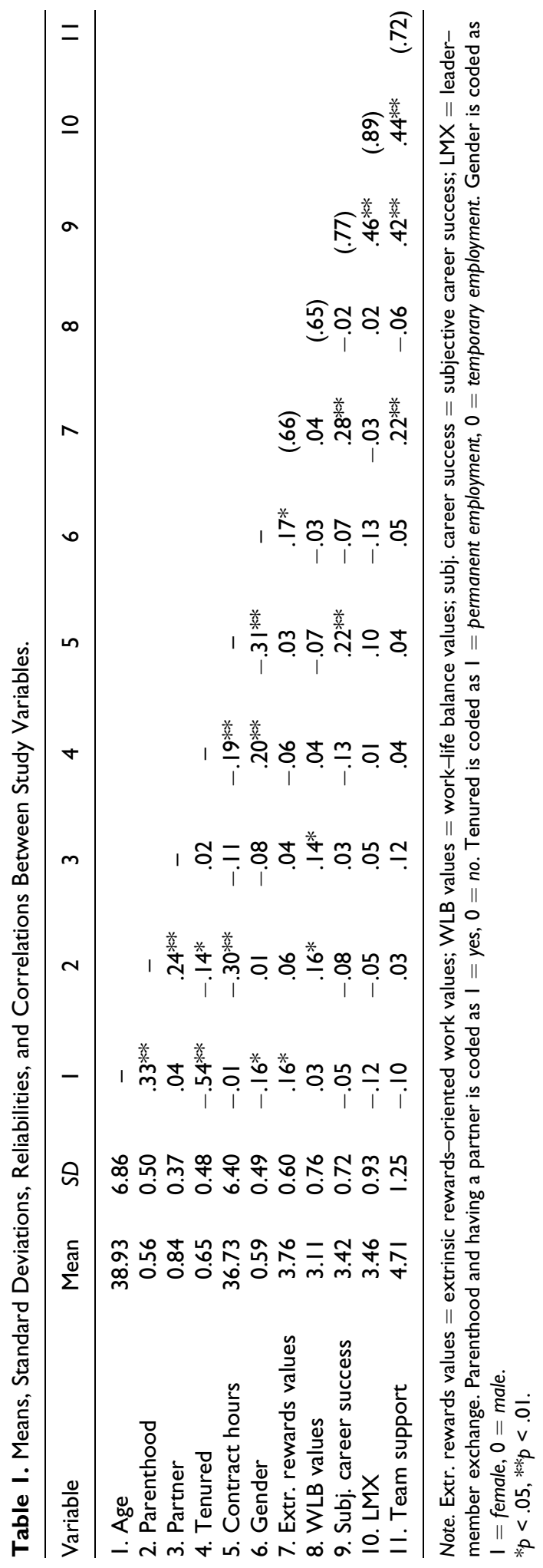




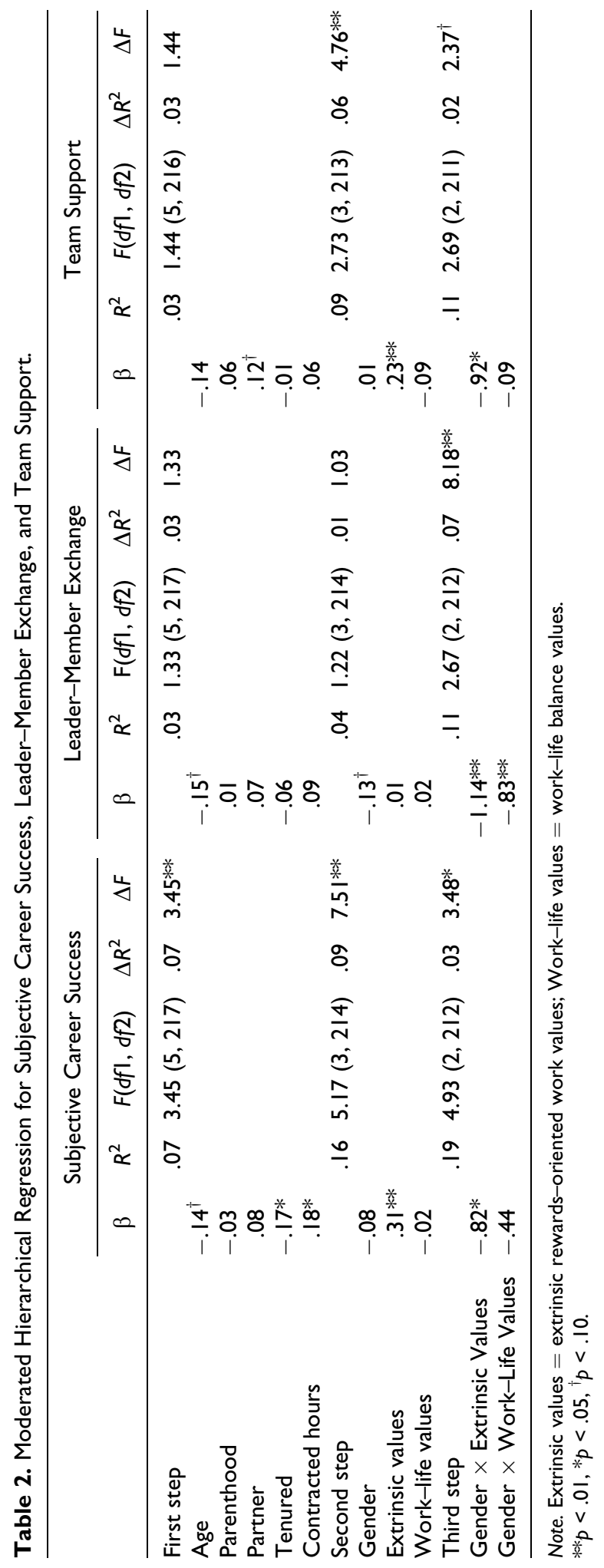




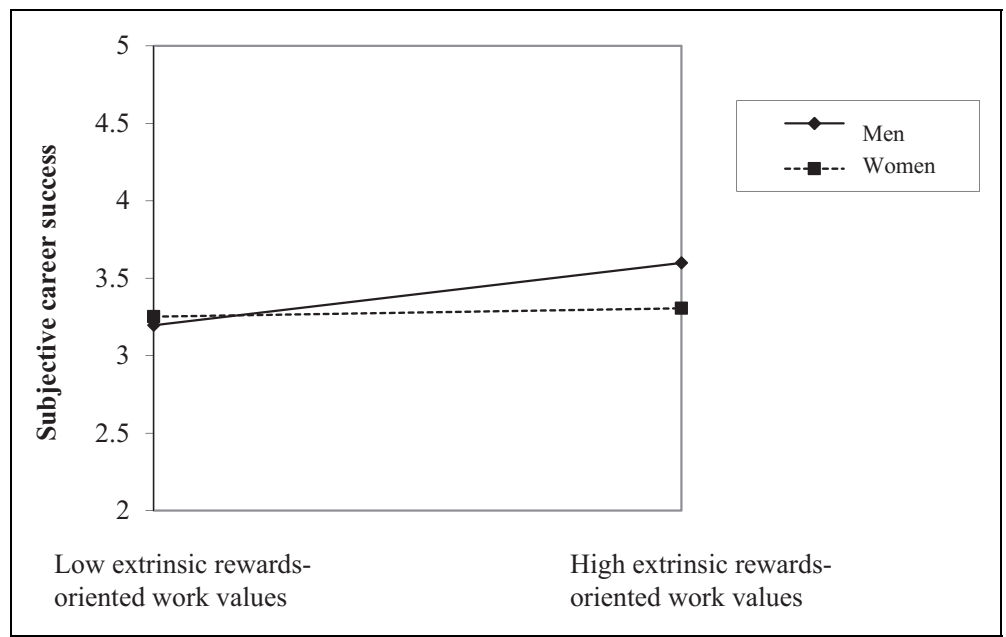

Figure I. The moderating role of gender in the relationship between extrinsic rewards-oriented work values and subjective career success.

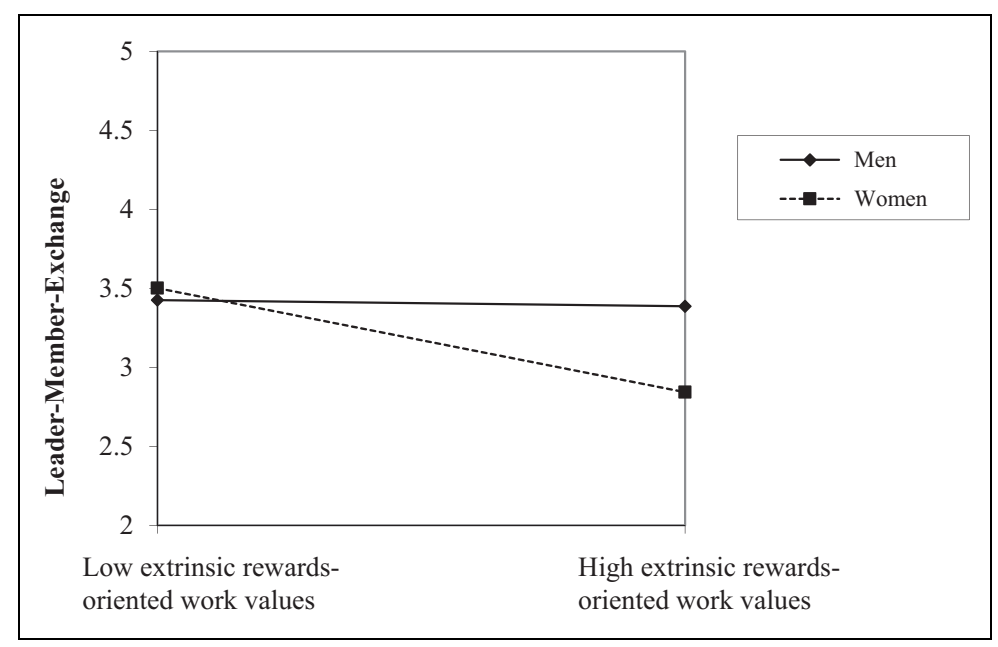

Figure 2. The moderating role of gender in the relationship between extrinsic rewards-oriented work values and leader-member exchange.

\section{Discussion}

Given the yet existing underrepresentation of woman in top positions of research, the present study seeks to contribute to our understanding of the processes and mechanisms underlying this phenomenon. Focusing on the postdoctoral career stage which is decisive in determining future career progress, the present study explored the role of work values for postdoctoral researchers' career success. Based on SCCT (Lent et al., 1994) and role congruity theory (Eagly \& Karau, 2002), we examined main as well as gender-differential impacts of extrinsic rewards-oriented work values and work-life balance values on subjective career success and career supports.

Supporting the notion of SCCT that values shape individual motivation, behaviors, and decisions, extrinsic rewards-oriented work values were positively related to subjective career success and team support (Bardi \& Schwartz, 2003; Lent et al., 1994). We propose that this positive link is based on 


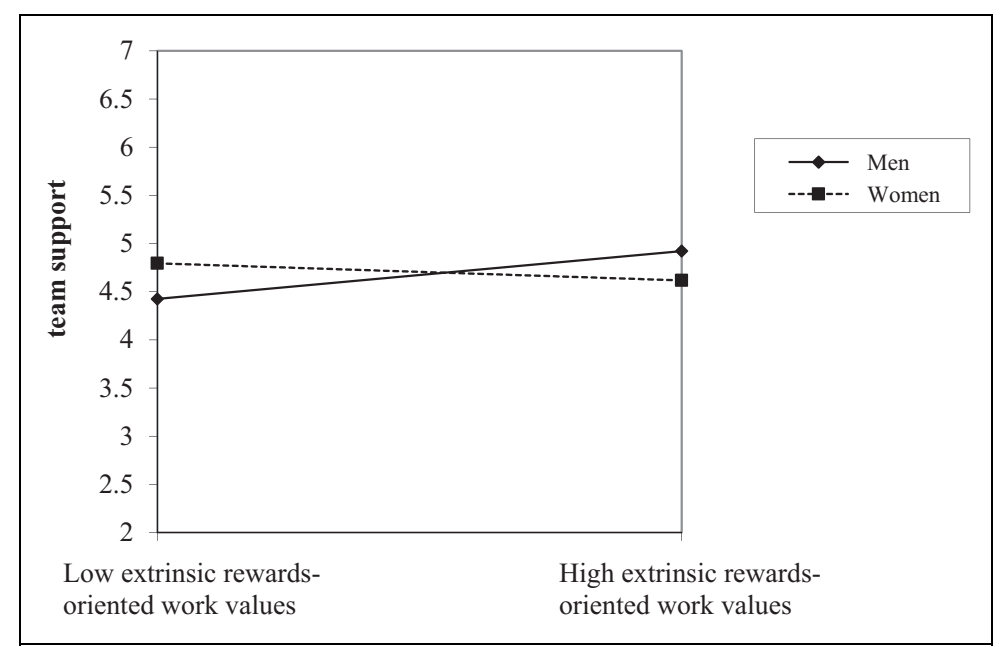

Figure 3. The moderating role of gender in the relationship between extrinsic rewards-oriented work values and team support.

values translating into attitudes and behaviors that are perceived and assessed by the social environment, affecting the supports granted by the team as well as affecting subjective success. By contrast, there was no association between work-life balance values and outcomes.

Aligned with the predictions of role congruity theory, we found gender-differential relationships between work values and subjective career success and career supports. Overall, male researchers mostly seem to benefit from increasing levels of extrinsic rewards-oriented values, whereas female researchers do not, or are even harmed, by these same values. We interpret these findings on the grounds of gendered information processing and attribution processes as part of the role congruity theory (Eagly \& Karau, 2002; Heilman \& Haynes, 2008). More precisely, given the misalignment of extrinsic rewards-orientation values with the expectation toward women to have a strong communal orientation, expressions of the extrinsic rewards-oriented work values (e.g., attitudes, behaviors) by women may go unnoticed, will not be stored in memory, or will not be recalled (Heilman \& Haynes, 2008). This corroborates previous findings that women's contributions in teams tend to be devalued (Heilman \& Haynes, 2005). For LMX as outcome, it seems that high extrinsic rewards orientation involves a penalty for women. High extrinsic rewards-oriented work values might be incompatible with female gender stereotypes such that for women, increasing extrinsic rewards-oriented work values are associated with egotism which in turn affects LMX.

We assume that the meaning of the work value and the associated behaviors are differentially attended to, interpreted, and recalled within the environment. Given the research design of our study, alternative mechanisms may also take an effect. Future research will have to test whether the way men and women express their work values differs systematically and whether differences in expression may account for our finding.

The hypotheses on work-life balance values were primarily not confirmed, with one exception. We found a negative relationship of work-life balance values with LMX for women but not for men. This finding confirms role congruity theory-work-life balance values unfold a negative effect for those individuals for whom those values are expected. The missing link between work-life balance values and the other outcomes might be interpreted in the light of organizational context: Whereas some research institutes might appreciate work-life balance orientation and see their employees as its most important resource, other research institutes might see research as a calling where work-life balance orientation is obstructive. Therefore, positive and negative effects of work-life balance orientation could neutralize each other. Future research should consider the impact of this organizational-level moderator. 
The gender-differential relationships dovetail with findings in cross-cultural research, where the relationship between work-life balance orientations with career advancement potential was contingent upon gender as well as on the country level of gender egalitarianism. In low gender egalitarianism countries, work-life balance orientation was positively related to career advancement potential for men but not for women (cf. Figures 2 and 3 in Lyness \& Judiesch, 2008, p. 798). In a study with 61 countries, Germany's score on gender egalitarianism fell only into the second quartile (cf. Figure 1 in Brodbeck, Frese, \& Javidan, 2002, p. 18). Furthermore, research as an occupational field is a setting with a comparatively low level of gender egalitarianism. Thus, our findings are similar to the findings of Lyness and Judiesch.

This study has some limitations. The cross-sectional design of our study implies that we cannot interpret our findings in terms of causal relationships. Thus, reversed as well as reciprocal relationships could also be possible. For example, career success could lead to higher extrinsic rewards orientation, with success serving as an amplifier. Or, lack of career success could result in higher work-life balance values, with nonwork commitments serving as a coping mechanism in the face of failure. Thus, more robust longitudinal designs need to test causal relationships.

The measures we used to assess work values had rather low reliabilities. Further research is required to develop robust measures of work values that are applicable to the context of research institutions.

The lack of an objective measure of career success is a further limitation. However, subjective measures of career success are an appropriate proxy of objective career success, especially when objective criteria are missing or of low variability (Heslin, 2005). We took care to select a subjective measure that converges with objective measures of success (Abele \& Spurk, 2009a). Furthermore, subjective measures appear to have predictive power for career development. Abele and Spurk (2009b) demonstrated in a prospective longitudinal study over 10 years that initial levels as well as changes in subjective career success had a strong influence on the growth of objective success.

Despite this, we cannot rule out the potential effects of a subjective bias. However, even if the findings of the present study should be attributed to a subjective bias, they are still likely to have "real" effects. One reason for the low prevalence of females in top positions is certainly the lower likelihood to ascend the career ladder. The second reason is that they voluntarily drop out in larger numbers than their male counterparts. Developing the impression that one is less successful and receives less careerrelevant support, despite holding the "right" values, may diminish self-efficacy and thus may be one reason for considering leaving the field (Singh et al., 2013).

We assume that our findings are based on the way people process information: information about individuals - values and the behaviors and attitudes through which they are expressed - are interpreted in line with expectations toward the actor. Whereas those effects can be, to a considerable extent, contained through the systematic use of formalized performance appraisals with transparent evaluation criteria (Heilman \& Haynes, 2008), our study suggests that there is still much to be learned about how to contain this effect in day-to-day interactions, among researchers and supervisors as well as among the research team.

Our findings have practical implications especially for supervisors in research institutions. The results suggest that supervisors should be aware of the gender-differential impact of work values on career success. For that, they should be ready to question their own assessments of female and male work-related values in combination with related career-relevant behaviors to prevent female penalties for behaving counterstereotypically. For example, extrinsic rewards-oriented female scientists who engage into self-promoting behavior could be perceived by supervisors as highly qualified, but also unlikeable, which could result in a backlash effect and promotion bypass (Rudman, 1998). Instead, supervisors should base their career-relevant selection and promotion decisions on objective sources of information and transparent assessment criteria (Heilman \& Haynes, 2008).

From another perspective, career counselors should help female scientists to reflect that appropriate work values have to be transformed into career-relevant behaviors and outcomes clearly visible for significant others. To compete with their male counterparts, female scientists should learn techniques of distinct self-promotion, visibility management (e.g., communicate abilities and accomplishments), 
and feedback seeking and should be ready to integrate these behaviors as an essential part of their role perception of excellent scientists.

\section{Declaration of Conflicting Interests}

The author(s) declared no potential conflicts of interest with respect to the research, authorship, and/or publication of this article. Both authors contributed equally to the study.

\section{Funding}

The author(s) disclosed receipt of the following financial support for the research, authorship, and/or publication of this article: This project was funded by Bundesministerium für Bildung und Forschung and Europäischer Sozialfonds (01 FP 0926 / 01 FP 0927).

\section{Note}

1. Postdoctoral researchers are typically paid at one of the two pay levels E13 to E14. These pay levels are part of a federal system of salary groups in the Civil Service of Germany. Any variation within these pay levels is more reflective of age or organizational tenure than individual performance.

\section{References}

Abele, A. E., \& Spurk, D. (2009a). How do objective and subjective career success interrelate over time? Journal of Occupational and Organizational Psychology, 82, 803-824. doi:10.1348/096317909x470924

Abele, A. E., \& Spurk, D. (2009b). The longitudinal impact of self-efficacy and career goals on objective and subjective career success. Journal of Vocational Behavior, 74, 53-62. doi:10.1016/j.jvb.2008.10.005

Abele, A. E., \& Wiese, B. S. (2008). The nomological network of self-management strategies and career success. Journal of Occupational and Organizational Psychology, 81, 733-749. doi:10.1348/096317907x256726

Aiken, L. S., \& West, S. G. (1991). Multiple regression: Testing and interpreting interactions. Newbury Park, CA: Sage.

Anderson, N. R., \& West, M. A. (1998). Measuring climate for work group innovation: Development and validation of the team climate inventory. Journal of Organizational Behavior, 19, 235-258. doi:10.1002/(SICI)10991379(199805)19:3<235:: AID-JOB837>3.0.CO;2-C

Bardi, A., \& Schwartz, S. H. (2003). Values and behavior: Strength and structure of relations. Personality and Social Psychology Bulletin, 29, 1207-1220. doi:10.1177/0146167203254602

Beutell, N. J., \& Brenner, O. C. (1986). Sex differences in work values. Journal of Vocational Behavior, 28, 29-41. doi:10.1016/0001-8791(86)90037-0

Blau, P. M. (1964). Exchange and power in social life. New York, NY: Wiley.

Bollen, K., \& Lennox, R. (1991). Conventional wisdom on measurement: A structural equation perspective. Psychological Bulletin, 110, 305-314. doi:10.1037/0033-2909.110.2.305

Brodbeck, F. C., Frese, M., \& Javidan, M. (2002). Leadership made in Germany: Low on compassion, high on performance. Academy of Management Executive, 16, 16-29.

Buckley, L. M., Sanders, K., Shih, M., Kallar, S., \& Hampton, C. (2000). Obstacles to promotion? Values of women faculty about career success and recognition. Academic Medicine, 75, 283-288. doi:10.1097/ 00001888-200003000-00021

Burrelli, J. (2008). Thirty-three years of women in $S \& E$ faculty positions. Info Brief Retrieved May, 15, 2013, from http://www.nsf.gov/statistics/infbrief/nsf08308/nsf08308.pdf

Dawson, J. F. (2013). Moderation in management research: What, why, when, and how. Journal of Business and Psychology. doi:10.1007/s10869-013-9308-7

De Dreu, C. K. W. (2007). Cooperative outcome interdependence, task reflexivity, and team effectiveness: A motivated information processing perspective. Journal of Applied Psychology, 92, 628-638. doi:10.1037/ 0021-9010.92.3.628

Dreher, G. F., \& Bretz, R. D. (1991). Cognitive ability and career attainment: Moderating effects of early career success. Journal of Applied Psychology, 76, 392-397. doi:10.1037/0021-9010.76.3.392 
Eagly, A. H., \& Karau, S. J. (2002). Role congruity theory of prejudice toward female leaders. Psychological Review, 109, 573-598. doi:10.1037/0033-295x.109.3.573

Eisenberger, R., Huntington, R., Hutchison, S., \& Sowa, D. (1986). Perceived organizational support. Journal of Applied Psychology, 71, 500-507. doi:10.1037/0021-9010.71.3.500

Elkins, T., \& Keller, R. T. (2003). Leadership in research and development organizations: A literature review and conceptual framework. The Leadership Quarterly, 14, 587-606. doi:10.1016/S1048-9843(03)00053-5

European_Commission. (2013). She figures 2012: Gender in research and innovation. Retrieved May, 20, 2013, from http://ec.europa.eu/research/science-society/document_library/pdf_06/she-figures-2012_en.pdf

Fay, D., Hüttges, A., \& Graf, P. (2013). Wissen um Aufstiegskriterien: Worauf kommt es für den Aufstieg in den Naturwissenschaften wirklich an? In K. Dautzenberg, D. Fay, \& P. Graf (Eds.), Aufstieg und Ausstieg (pp. 27-41). Wiesbaden, Germany: VS-Verlag.

Ferriman, K., Lubinski, D., \& Benbow, C. P. (2009). Work preferences, life values, and personal views of top math/science graduate students and the profoundly gifted: Developmental changes and gender differences during emerging adulthood and parenthood. Journal of Personality and Social Psychology, 97, 517-532. doi:10.1037/a0016030

Frieze, I. H., Olson, J. E., Murrell, A. J., \& Selvan, M. S. (2006). Work values and their effect on work behavior and work outcomes in female and male managers. Sex Roles, 54, 83-93. doi:10.1007/s11199-006-8871-z

Gerstner, C. R., \& Day, D. V. (1997). Meta-analytic review of leader-member exchange theory: Correlates and construct issues. Journal of Applied Psychology, 82, 827-844. doi:10.1037/0021-9010.82.6.827

Graen, G. B., \& Uhl-Bien, M. (1995). Relationship-based approach to leadership: Development of leader-member exchange (LMX) theory of leadership over 25 years: Applying a multi-level multi-domain perspective. The Leadership Quarterly, 6, 219-247. doi:10.1016/1048-9843(95)90036-5

Graf, P., Dautzenberg, K., Büttner, N., \& Schmid, S. (2011). Frauenkarrieren in der Wissenschaft: Eine vergleichende Analyse des Status quo. In K. Dautzenberg, D. Fay, \& P. Graf(Eds.), Frauen in den Naturwissenschaften: Ansprüche und Widersprüche (pp. 19-46). Wiesbaden, Germany: VS-Verlag.

Hadani, M., Coombes, S., Das, D., \& Jalajas, D. (2012). Finding a good job: Academic network centrality and early occupational outcomes in management academia. Journal of Organizational Behavior, 33, 723-739. doi:10.1002/job.788

Heilman, M. E. (2001). Description and prescription: How gender stereotypes prevent women's ascent up the organizational ladder. Journal of Social Issues, 57, 657-674. doi:10.1111/0022-4537.00234

Heilman, M. E., \& Chen, J. J. (2005). Same behavior, different consequences: Reactions to men's and women's altruistic citizenship behavior. Journal of Applied Psychology, 90, 431-441. doi:10.1037/0021-9010.90.3.431

Heilman, M. E., \& Haynes, M. C. (2005). No credit where credit is due: Attributional rationalization of women's success in male-female teams. Journal of Applied Psychology, 90, 905-916. doi:10.1037/0021-9010.90.5.905

Heilman, M. E., \& Haynes, M. C. (2008). Subjectivity in the appraisal process: A facilitator of gender bias in work settings. In E. Borgida \& S. T. Fiske (Eds.), Beyond common sense: Psychological science in the courtroom (pp. 127-155). Malden, MA: Wiley Blackwell.

Heslin, P. A. (2005). Conceptualizing and evaluating career success. Journal of Organizational Behavior, 26, 113-136. doi:10.1002/job.270

Hirschi, A. (2010). Positive adolescent career development: The role of intrinsic and extrinsic work values. The Career Development Quarterly, 58, 276-287.

Holst, E., \& Schimeta, J. (2011). 29 von 906: Weiterhin kaum Frauen in Top-Gremien großer Unternehmen. DIW Wochenbericht, 78, 2-10.

Judge, T. A., Kammeyer-Mueller, J., \& Bretz, R. D. (2004). A longitudinal model of sponsorship and career success: A study of industrial-organizational psychologists. Personnel Psychology, 57, 271-303. doi:10.1111/j. 1744-6570.2004.tb02492.x

Jungbauer-Gans, M., \& Gross, C. (2013). Determinants of success in university careers: Findings from the German academic labor market. Zeitschrift für Soziologie, 42, 74-92.

Konrad, A. M., Corrigall, E., Lieb, P., \& Richie, J. E., Jr. (2000). Sex differences in job attribute preferences among managers and business students. Group \& Organization Management, 25, 108-131. doi:10.1177/ 1059601100252002 
Konrad, A. M., Ritchie, J. E., Jr., Lieb, P., \& Corrigall, E. (2000). Sex differences and similarities in job attribute preferences: A meta-analysis. Psychological Bulletin, 126, 593-641. doi:10.1037/0033-2909.126.4.593

Konrad, A. M., Yang, Y., Goldberg, C., \& Sullivan, S. E. (2005). Preferences for job attributes associated with work and family: A longitudinal study of career outcomes. Sex Roles, 53, 303-315. doi:10.1007/s11199005-6754-3

Lent, R. W., \& Brown, S. D. (2013). Social cognitive model of career self-management: Toward a unifying view of adaptive career behavior across the life span. Journal of Counseling Psychology, 60, 557-568.

Lent, R. W., Brown, S. D., \& Hackett, G. (1994). Toward a unifying social cognitive theory of career and academic interest, choice, and performance. Journal of Vocational Behavior, 45, 79-122.

Lent, R. W., Brown, S. D., \& Hackett, G. (2002). Social cognitive career theory. In D. Brown (Ed.), Career choice and development (4th ed., pp. 255-311). San Francisco, CA: Jossey-Bass.

Lind, I., \& Löther, A. (2007). Chancen für Frauen in der Wissenschaft - eine Frage der Fachkultur? Retrospektive Verlaufsanalysen und aktuelle Forschungsergebnisse. Schweizerische Zeitschrift für Bildungswissenschaften, 29, 249-272.

Ludlow, C. L., \& Kent, R. D. (2011). Building a research career. San Diego, CA: Plural.

Lyness, K. S., \& Judiesch, M. K. (2008). Can a manager have a life and a career? International and multisource perspectives on work-life balance and career advancement potential. Journal of Applied Psychology, 93, 789-805. doi:10.1037/0021-9010.93.4.789

Miller, C. C., Glick, W. H., \& Cardinal, L. B. (2005). The allocation of prestigious positions in organizational science: Accumulative advantage, sponsored mobility, and contest mobility. Journal of Organizational Behavior, 26, 489-516. doi:10.1002/job.325

Ng, T. W. H., Eby, L. T., Sorensen, K. L., \& Feldman, D. C. (2005). Predictors of objective and subjective career success. A meta-analysis. Personnel Psychology, 58, 367-408.

Rudman, L. A. (1998). Self-promotion as a risk factor for women: The costs and benefits of counterstereotypical impression management. Journal of Personality and Social Psychology, 74, 629-645.

Schyns, B. (2002). Überprüfung einer deutschsprachigen Skala zum Leader-Member-Exchange-Ansatz. Zeitschrift für Differentielle und Diagnostische Psychologie, 23, 235-245.

Singh, R., Fouad, N. A., Fitzpatrick, M. E., Liu, J. P., Cappaert, K. J., \& Figuereido, C. (2013). Stemming the tide: Predicting women engineers' intentions to leave. Journal of Vocational Behavior, 83, 281-294. doi: 10.1016/j. jvb.2013.05.007

Turner, R. H. (1960). Sponsored and contest mobility and the school system. American Sociological Review, 25, $855-867$.

Warr, P. (2008). Work values: Some demographic and cultural correlates. Journal of Occupational and Organizational Psychology, 81, 751-775. doi:10.1348/096317907x263638

\section{Author Biographies}

Annett Hüttges received her PhD from the Technische Universität Dresden, Germany. She worked in various research projects at Technische Universität Dresden, University of Potsdam and, as professor of work and organizational psychology, at Medical School Berlin. Additionally, she worked as a management consultant for companies in the public and private sector. Currently, she is responsible for human resources development at GFZ German Research Centre for Geosciences in Potsdam. Her research focuses on gender differences in career development. Furthermore, she is interested in topics of occupational health psychology. In her free time, she enjoys salsa dancing, going to the cinema, and being with her family.

Doris Fay is a full professor of work and organizational psychology at the University of Potsdam, Germany. She received her PhD from the University of Amsterdam, The Netherlands, and worked as senior lecturer at Aston Business School, UK. Her research focuses on proactivity and personal initiative, creativity and innovation, and well-being at work. Furthermore, she is interested in gendered career development. In her free time, she enjoys being with her family, music, reading, and traveling. 